\title{
Lightweight concrete with Algerian limestone dust. Part II: study on $50 \%$ and $100 \%$ replacement to normal aggregate at timely age
}

\section{(Concreto leve a partir de pó de calcário. Parte II: estudo de substituição de $50 \%$ e $100 \%$ do agregado normal)}

\author{
S. Kitouni ${ }^{1}$, H. Houari ${ }^{2}$ \\ ${ }^{1}$ Pharmaceutical Engineering Faculty, Constantine University 3, Constantine 25000, Algeria \\ ${ }^{2}$ Laboratoire Matériaux et Durabilité des Constructions - LMDC, Department of Civil Engineering, \\ University of Constantine, Constantine, Algeria \\ souad0714@yahoo.fr
}

\begin{abstract}
A control lightweight concrete (LWC) mixture made with $50 \%$ and $100 \%$ of limestone as a replacement of coarse aggregates in weight was prepared. Limestone is used for economical and environmental concern. The concrete samples were cured at $65 \%$ relative humidity at $20{ }^{\circ} \mathrm{C}$. The compressive and flexural tensile strengths, elastic modulus and Poisson's ratio of hardened concrete were measured. Laboratory compressive and tensile strength tests results showed that LWC can be produced by the use of limestone. The aim of this study is twofold: one is to design a lightweight concrete with the use of limestone that will provide an advantage of reduction in dead weight of a structure; and second is to obtain a more economical LWC mixture with the use of limestone. Keywords: lightweight aggregate concrete, limestone dust, flexural tensile strength, elastic modulus, compressive strength.
\end{abstract}

\section{Resumo}

Foi preparada uma mistura de concreto leve feita com 50\% e 100\% de calcário como substituição de agregados graúdos em peso. O calcário é utilizado com finalidade econômica e preocupação ambiental. As amostras de concreto foram curadas a $65 \%$ de umidade relativa a $20^{\circ} \mathrm{C}$. As resistências à compressão e à tensão de flexão, o módulo de elasticidade e razão de Poisson do concreto endurecido foram medidos. Testes de laboratório de resistência à compressão e à tração mostraram que concretos leves podem ser produzidos com calcário. O objetivo deste estudo é duplo: um é projetar um concreto leve com o uso de calcário que irá proporcionar uma vantagem de redução de peso morto de uma estrutura; e o segundo é obter uma mistura de concreto leve com o uso de calcário. Palavras-chave: concreto leve agregado, pó de calcário, resistência à tração, resistência à flexão, módulo de elasticidade, resistência à compressão.

\section{INTRODUCTION}

The benefit of LWC as structural material was recognized as far back as Roman days. Nevertheless, the production of lightweight aggregates began on a larger scale after the First World War. In fact, it is mentioned in the literature that the first practical use of lightweight concrete took place at that time, when American Emergency Fleet Corporation built lightweight concrete ships. Its use has increased progressively ever since, so that today lightweight aggregates (LWA) represent a significant part of the total quantity of the aggregates intended for use in construction. Depending on its density, lightweight aggregate can be used in several ways [1]: - in the production of concrete, concrete blocks, and other precast products, where improved thermal insulating properties are needed; - for the rehabilitation of buildings of historical importance, where gravel or rubble was used originally to ensure the weight and acoustic insulation of a floor/ceiling structure. In these cases, especially if the overall earthquake resistance of the building has to be increased, the gravel is replaced by lightweight aggregate, and this way the deadweight of the structure is reduced; - in various applications, where material with a low self-weight is specified by the designer.

Lightweight aggregates are broadly classified in to two types, natural and artificial. The production of lightweight aggregate concrete has been expanding, and now includes all types-from no-fines concrete of low density, mainly for block production with densities from 300 to $1200 \mathrm{~kg} / \mathrm{m}^{3}$, to structural concrete with densities from 1000 to $2000 \mathrm{~kg} / \mathrm{m}^{3}$ and compressive strengths from 1 to $100 \mathrm{MPa}$ [2].

In concrete construction, the concrete represents a very large proportion of the total load on the structure, and there are clearly considerable advantages in reducing its density. One of the ways to reduce the weight of a structure is the use of lightweight aggregate concrete (LWC). Many authors in their investigations reported that lightweight concrete (LWC) has its obvious advantages of high strength/weight ratio, good tensile strength, low coefficient of thermal expansion, and superior heat and sound insulation characteristic due to air voids in lightweight aggregate (LWA). Furthermore, with lighter concrete, the formwork supports less pressure 
than would be the case with ordinary concrete, and also the total weight of materials to be handled is reduced with a consequent increase in productivity.

Lightweight concrete is generally used to reduce the dead weight of a structure as well as to reduce the risk of earthquake damages to a structure because the earthquake forces that will influence the civil engineering structures and buildings are proportional to the mass of those structures and buildings. The reduction in the dead weight of a construction by the use of lightweight aggregates in concrete could result in a decrease in the cross-section of steel reinforced columns, beams, plates, and foundations. It is also possible to reduce steel reinforcement. Thus, reducing the mass of the structure or building is of utmost importance to reduce their risk due to earthquake acceleration [3].

In the last few decades, considerable research effort has been spent on the utilization of industrial by-products (fly ash, blast-furnace slag, microsilica, etc.) and natural resources (limestone, pozzolan, etc.) as partial replacement of coarse aggregate. Limestone fillers are notably used as replacement materials. As the properties of fresh and hardened concrete depends on the intrinsic properties of fines, notably the socalled "filler effect", the use of these by-products requires a thorough characterization. Rheological problems may be solved usually by means of admixtures and viscosity agents. Limestone fillers are quite abundant and already used in several applications: they are actually cheaper and less polluting. These are the reasons why limestone fillers were investigated.The effects of this material on fresh concrete properties and the influence on hardened concrete properties have been already pointed out [4].

Since LWC is an economical alternative to other forms of construction the use can become more economical. There are vast amounts of studies on use of lightweight aggregates either in structural lightweight concrete production or lightweight concrete block $[5,6]$. However, there are only few published studies on the use of limestone. It is understood that limestone dust cannot be used efficiently as a cementitious material and plays a fine aggregate and a filler material role. Considering the availability of limestone dust in Algeria and its usability as a natural lightweight aggregate for concrete, a research program has been carried out in order to study the comparative performance of concrete using limestone dust as lightweight coarse aggregate. This paper presents a part of the results of an ongoing laboratory work carried out to design a lightweight concrete (LWC) made with limestone. The main results at the actual stage of this research are presented through the paper. Comprehensive research has been carried out on the development of LWC with limestone dust having satisfactory strength and durability characteristics.

\section{EXPERIMENTAL PROCEDURE}

Algerian Grade 42.5 ordinary silicate cement of with qualified stability was purchased from El Hamma carrier (Constantine, Algeria), the tap-water, the natural sand in middle fineness was purchased from E.N.G carrier (Constantine, Algeria), and the fine limestone was used and was purchased also from E.N.G carrier. The properties of fine limestone are summarized in Table I.

The normal weight aggregate used was grading of 3-8 $\mathrm{mm}$ with specific gravity of $2.7 \mathrm{~g} / \mathrm{cm}^{3}$ and was purchased from E.N.G carrier. The superplasticizer used is SP40. The mixture was prepared by replacing $50 \%$ and $100 \%$ weight of

Table I - Properties of limestone. [Tabela I - Propriedades do pó de calcário.]

\begin{tabular}{lc}
\hline Specific gravity $\left(\mathrm{g} / \mathrm{cm}^{3}\right)$ & 2.7 \\
\hline Whiteness & $92 \%$ \\
Moisture & $0.1 \%$ \\
\hline
\end{tabular}

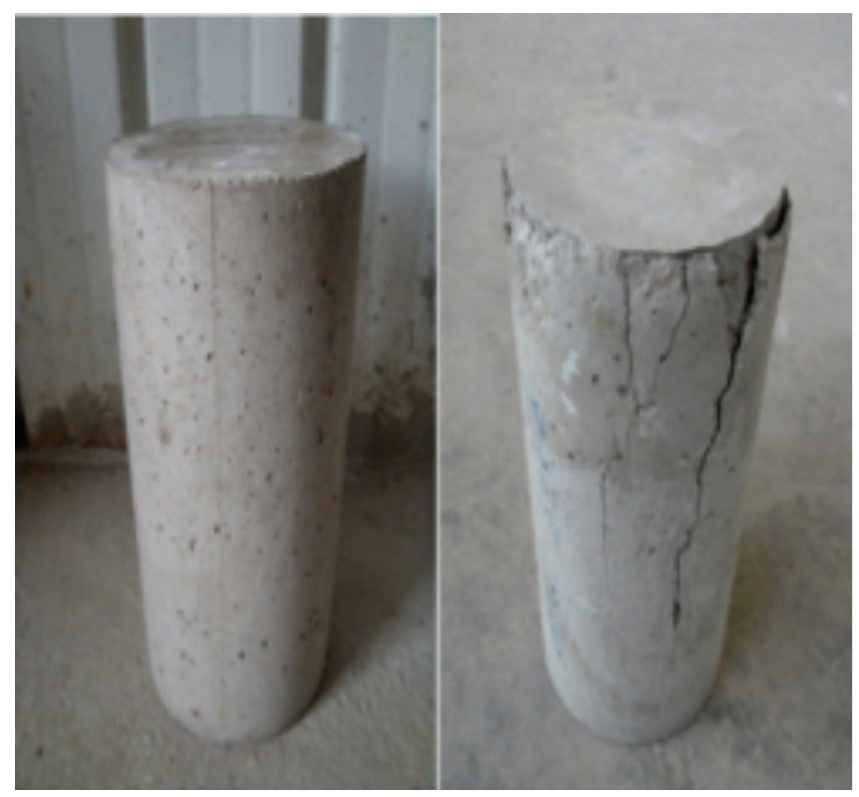

Figure 1: Cylinder $16 \mathrm{~cm}$ x $32 \mathrm{~cm}$ before and after test. [Figura 1: Cilindro de $16 \mathrm{~cm} \times 32 \mathrm{~cm}$ antes e depois do teste.]

Table II - Mix proportions by weight (cement: sand: limestone).

[Tabela II - Proporções em peso da mistura (cimento: areia: pedra calcária).]

\begin{tabular}{cccccc}
\hline \multirow{2}{*}{ Fraction of limestone (\%) } & \multicolumn{7}{c}{ Mix Proportion by weight } & & \\
& Cement & Sand & Limestone & Coarse aggregates & Water \\
\hline 50 & 1 & 1.976 & 1.482 & 1.482 & 0.65 \\
100 & 1 & 1.976 & 2.964 & - & 0.83 \\
\hline
\end{tabular}




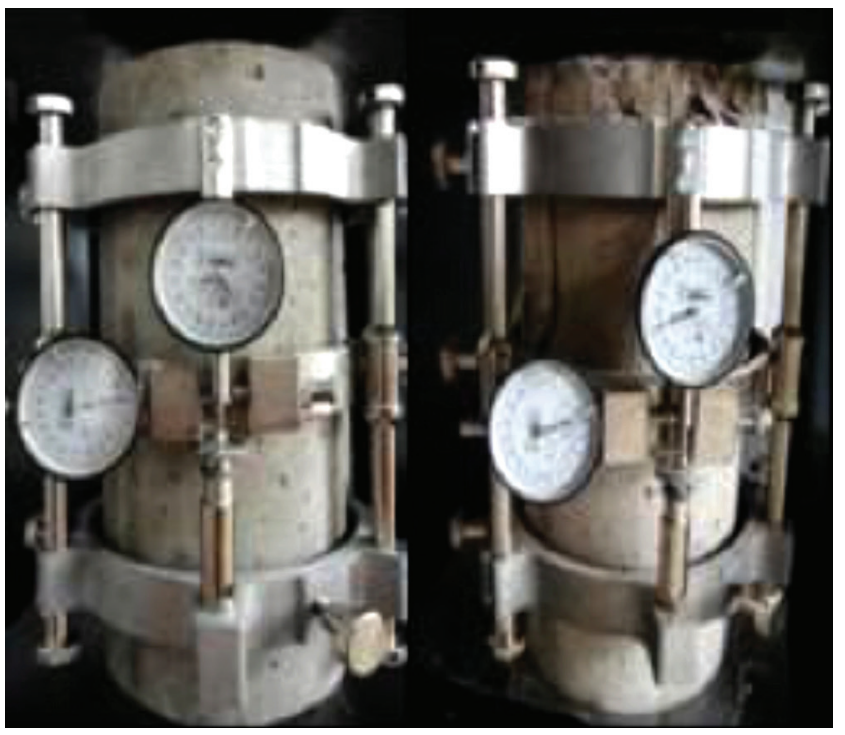

Figure 2: Elastic modulus test.

[Figura 2: Teste do módulo elástico.]
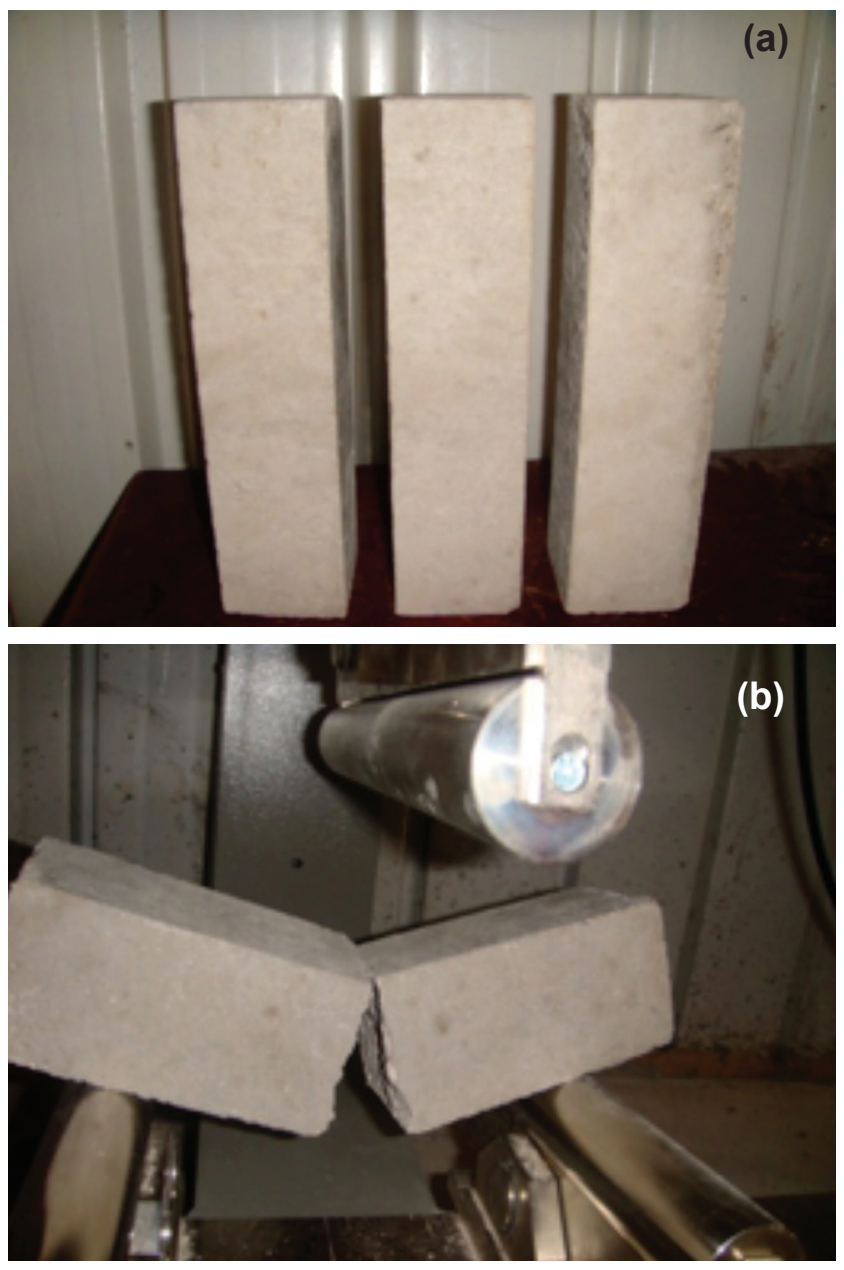

Figure 3: Beams before and after test.

[Figura 3: Vigas antes e depois do teste.]

normal aggregate by limestone (Table II).

The cylinders of $160 \mathrm{~mm} \times 320 \mathrm{~mm}$ (Fig. 1) were tested for the axial compressive strength and elastic modulus of concrete (Fig. 2), the beams of $70 \mathrm{~mm} \times 70 \mathrm{~mm} \times 280 \mathrm{~mm}$ were tested for the flexural tensile strength of concrete (Fig. 3). The strengths and elastic modulus of the concrete samples were determined at the ages of 28 days.

\section{RESULTS AND DISCUSSIONS}

The object of physico-mechanical tests to examine whether the samples satisfy with requirements of relevant international standards for using on construction applications. All of the results obtained from tests are mainly listed in Table III.

Density is one of the important parameters which can control many physical properties in lightweight concrete and it is mainly controlled by the amount and density of lightweight aggregate.The bulk density of the structural lightweight concretes (ranging between 1400 and $2000 \mathrm{~kg} / \mathrm{m}^{3}$ ) were discovered to be sensibly lower than that of an ordinary concrete (usually between 2200 and $2600 \mathrm{~kg} / \mathrm{m}^{3}$ ) and conform with others works [7].Air dry densities are given in Table III. The 28-day density in surface dry condition is $2027 \mathrm{~kg} / \mathrm{m}^{3}$ for $50 \%$ of replacement of coarse aggregates and $1951 \mathrm{~kg} / \mathrm{m}^{3}$ for $100 \%$ of replacement of coarse aggregates. If taken the density of normal weight concrete as $2400 \mathrm{~kg} / \mathrm{m}^{3}$, there is a saving in the self-weight $16 \%$ for $50 \%$ of replacement of coarse aggregates and $19 \%$ for

Table III - Density, compressive strength, flexural strength, modulus of elasticity, static modulus of elasticity, dynamic modulus of elasticity \& Poisson ratio results.

[Tabela III - Densidade, resistência a compressão, resistência a flexão, modulo de elasticidade, modulo de elasticidade estático, modulo de elasticidade dinâmico e relação de resultados Poisson.]

\begin{tabular}{lcc}
\hline Density $\left(\mathrm{kg} / \mathrm{m}^{3}\right)$ & $50 \%$ & 2027.46 \\
& $100 \%$ & 1950.95 \\
\hline Compressive strength $\left(f_{c}\right)(\mathrm{MPa})$ & $50 \%$ & 23.10 \\
& $100 \%$ & 12.10 \\
\hline \multirow{2}{*}{ Flexural strength $(\mathrm{MPa})$} & $50 \%$ & 6.76 \\
\hline \multirow{2}{*}{ Modulus of elasticity E $(\mathrm{GPa})$} & $100 \%$ & 5.96 \\
\hline \multirow{2}{*}{ Static modulus of elasticity $(\mathrm{GPa})$} & $50 \%$ & 25.90 \\
\hline Dynamic modulus of elasticity & $100 \%$ & 16.00 \\
\hline GPa) & $50 \%$ & 23.20 \\
\hline Poisson's Ratio $(\gamma)$ & $100 \%$ & 20.26 \\
\hline
\end{tabular}


$100 \%$ of replacement of coarse aggregates. This means that the earthquake forces will be reduced by about $16 \%$ and $19 \%$ if a structure or building is made with those concretes. The reduced weight may make it preferable for structures in seismic zones because of the reduced dynamic actions. In recent years, many experimental researches have been done on the seismic behavior of lightweight concrete shear walls. However, due to the financial and the time reason, it is not enough that only getting the results from experiments. Finite element method supplied a new way to study shear walls by computer, which can help the researcher to analyze and complete the experimental results and have a better understanding of it. In recent years, using ANSYS finite element software, many research works have been done successfully to simulate the seismic behavior of reinforced concrete shear walls. This software has plentiful element types and offers some default parameters, which make it easy to develop the model to simulate the cooperation work of concrete and other materials [8]. The density decreased with the increase of water cement ratio $(\mathrm{w} / \mathrm{c})$. This is attributed to the fact that the water content increases with the increasing $\mathrm{w} / \mathrm{c}$ ratio, and water is lighter than cement. Besides, once the amount of free water contained in the pores of the paste evaporates, the result is an increase in the size of the pores and porosity in cement paste and thus reducing weight of the resulting concrete. Furthermore, the effects of filling ratio of sand on the density did not match expected, although sand and limestone have lighter specific gravity than cement [9].

As a matter of fact, it is necessary to increase the amount of kneading water when the content of fillers is increased, in order to ensure the proper concrete workability. This effect is clearer when $100 \%$ is used, probably due to the presence of a higher amount of finer particles in the concrete, since this filler contains particles of lower dimensions. Furthermore, limestone dust also presents higher water absorption, in accordance with previous observations. Altogether, the apparent density of the concrete paste decreases with the increase of LW fillers not only because of the direct effect of introducing Light weight materials but also due to the increase in air content inside the concrete. However, the increase in the amount of limestone dust clearly causes an increase in the pore size but also in the amount of larger pores. Since limestone is made of fine particles we might admit the occurrence of agglomeration during preparation and mixing of samples. Coarser agglomerates are then able to absorb and sequestrate a relatively high volume of water that leaves larger pores once removed upon curing [10].

The cylinder compressive strengths of the concrete studied are given in Table III. The 28-day compressive strength in surface dry condition was $23.10 \mathrm{MPa}$ for $50 \%$ replacement and $12.10 \mathrm{MPa}$ for $100 \%$ replacement. It shows that $50 \%$ replacement of coarse by limestone surpassed the compressive $100 \%$ replacement of coarse by limestone at 28 days and beyond. With the increase of the content of limestone, the compressive strength increased significantly, this indicated that limestone played an important role in the system. Limestone not only acted as a necessary component

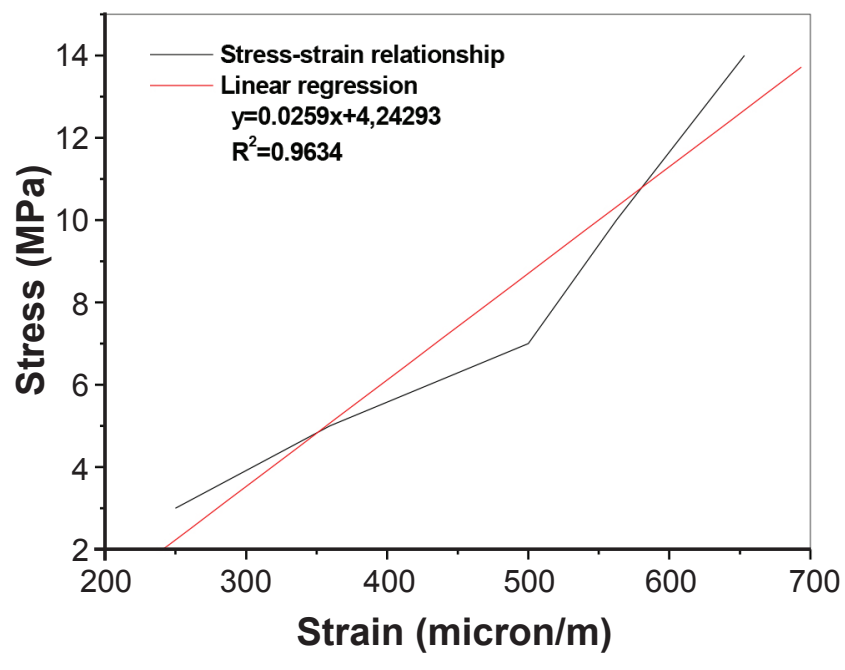

Figure 4: Elastic modulus at 28 days. [Figura 4: Modulo de elasticidadeaos 28 dias.]

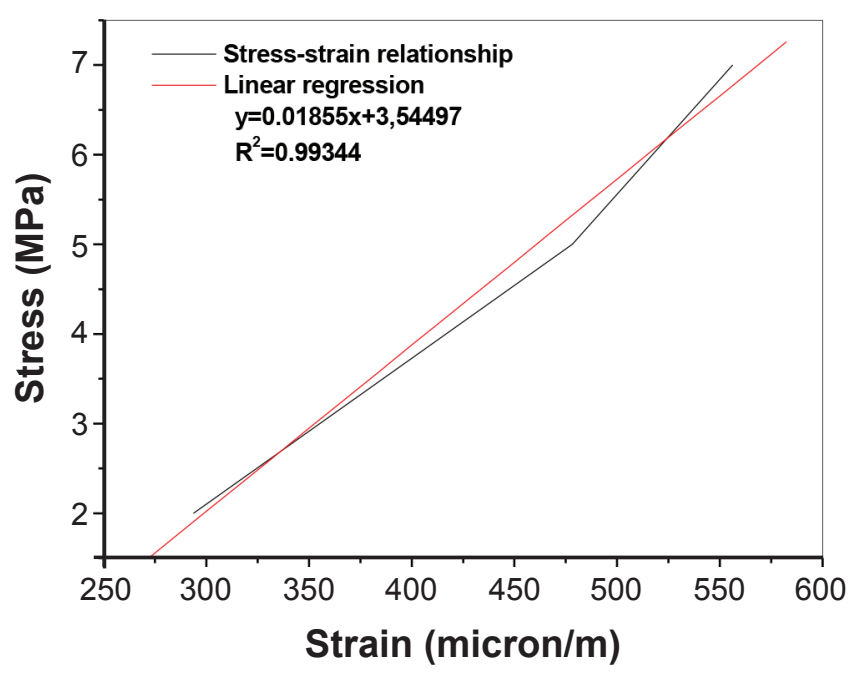

Figure 5: Elastic modulus at 28 days.

[Figura 5: Modulo de elasticidade aos 28 dias.]

of silica-calcium reaction, but also activated other hydrate reactions in PG-fly ash-lime system. Moreover, limestone could eliminate the negative effect of acid and organic impurities on the strength to some extent [11].

The compressive strength result for $50 \%$ replacement by limestone is found to be satisfactory for structural lightweight concrete, since the lower limit of compressive strength for structural lightweight concrete is $17 \mathrm{MPa}$ [3]. The compressive strength of the concrete is one of the most important factors and is usually used to judge the concrete quality and its fitness. Currently, as the importance of concrete durability is gaining recognition and acceptance, it is also becoming a major consideration in concrete structure design. The use of limestone dust results in an increase in compressive strength. This is probably due to the fineness of the particles and the irregular particle shape. The smaller particles could also fill in the voids of the concrete mixture, 
thus increasing the compressive strength of the concrete [12].

The compressive strength of lightweight concrete is controlled by the feature of lightweight aggregates (LWA), as indicated in ACI 213 codes as the strength ceiling of LWC. The compressive strength of LWC can be divided into two phases. The mortar phase containing cement, water and sand mainly supports the strength of LWC, and the LWA phase mainly reduces the density of LWC [13]. While the bulk density of the structural lightweight concrete was within acceptable range, additional to the result of compressive strength was discovered to be within the acceptable range of structural lightweight concretes [7]. Compressive strength is affected by interrelated factors, such as the density and shape of the aggregates, the surface features, water absorption, pore size and distribution. In general, the best compressive strength values are achieved with the highest dry particle density. This fact leads to the creation of a parameter that represents a measure of compromise obtained between the needs of high resistance and low density for certain applications [14].

The elastic modulus of concrete can be determined by static modulus of elasticity tests or by the secant modulus of the stress-strain curves resulting from compressive tests. In this study, the second method was used and the measured E value was compared with static modulus of elasticity estimated by empirical formulae. The Evalue of the concrete at 28 days is about $25.90 \mathrm{GPa}$ for $50 \%$ replacement (Fig. 4) and $18.55 \mathrm{GPa}$ for $100 \%$ replacement (Fig. 5).

Porosity of aggregate affects the modulus of elasticity of concrete, which controls the ability of aggregate to restrain matrix strain [15]. In the main, the development of $\mathrm{E}$ is influenced by type of coarse aggregate, type of cement, w/c ratio of the mix and curing age. The $\mathrm{E}$ of lightweight aggregate concrete is usually between $40 \%$ and $80 \%$ of ordinary concrete of the same strength [16]. The E of concrete is a function of compressive strength. Various building codes have provided empirical equations relating $\mathrm{E}$ and compressive strength. The $\mathrm{E}$ value of concrete also depends on the stiffness of coarse aggregate, interfacial zone between the aggregates and paste and the elastic properties of constituent materials [16].The statistical analysis carried out to obtain the power relationship between the modulus of elasticity and compressive strength yielded the following equations for the lightweight concretes [17]:

$$
\begin{aligned}
& \text { Static modulus: } \mathrm{E}_{\mathrm{s}}=8.8 \mathrm{fc}^{0.24} \\
& \text { Dynamic modulus: } \mathrm{E}_{\mathrm{d}}=12.0 \mathrm{fc}^{0.21}
\end{aligned}
$$

where E: modulus of elasticity $\left[\mathrm{kN} / \mathrm{mm}^{2}\right]$, compressive strength $\left[\mathrm{N} / \mathrm{mm}^{2}\right]$.

The values of $\mathrm{E}_{\mathrm{s}}$ and $\mathrm{E}_{\mathrm{d}}$ are listed in Table III. The calculated 28-day value of $\mathrm{E}$ using equation (A) is $18.70 \mathrm{GPa}$ for $50 \%$ replacement and $16.00 \mathrm{GPa}$ for $100 \%$ replacement. This decrease may be attributed to the porous structure of the lightweight aggregate and the presence of internal voids between particles [18]. It is commonly known that concretes with lower compressive strength have lower E values [19]. In equation (A), $\mathrm{f}_{\mathrm{c}}$ is the cube compressive strength. The above values of $18.70 \mathrm{GPa}$ and $16.00 \mathrm{GPa}$ were obtained using cylinder strength value of $25.10 \mathrm{MPa}$ (respectively $12.10 \mathrm{MPa}$ ). If the cylinder strength were converted into equivalent cube strength, the estimated value of $\mathrm{E}$ would be even greater than $18.70 \mathrm{GPa}$ for $50 \%$ replacement and $16.00 \mathrm{GPa}$ for $100 \%$ replacement. More often than not, the empirical formulae are reported to overestimate the $\mathrm{E}$ value of lightweight concretes However, for the concrete reported here the calculated $\mathrm{E}$ values are less than the observed value.

In a situation where the static modulus of elasticity of a particular mix of concrete may not be readily available for design purposes, it will be quicker and convenient to determine the dynamic modulus, and the static modulus of lightweight concrete can then be determined from the following recommended equation [17]:

$$
\mathrm{E}_{\mathrm{S}}=0.87 \mathrm{E}_{\mathrm{d}}-0.78 \pm 3 \mathrm{kN} / \mathrm{mm}^{2}
$$

This equation should give satisfactory results for most of the structural lightweight aggregate concretes.

Compared to the compressive behavior of concrete, its tensile behavior has received a little attention in the past, partly because it is a common practice to ignore tensile resistance in reinforced concrete design. Interest in tensile properties has grown substantially in recent years partially due to introduction of fracture mechanics into the field of concrete structures. In addition, the flexural tensile of concrete is important to resist cracking from shrinkage and temperature changes.

The flexural tensile of concrete specimens were measured for 28 day of curing. It isconcludedthat the concretestrengthdepends on thestrength, stiffness and density of coarse aggregates. For building materials to be used in structural applications, the minimum flexural tensile strength requires is $0.65 \mathrm{MPa}$ [20]. Flexural strength decreases with increasing LWA content as predicted. In the lightweight aggregate concrete, lightweight aggregate is weaker than the bond strength between aggregate and cement paste, so that fracture occurs within the aggregate. Increasing LWA content, the number of LWA particles per unit cross section increases leading to lower strength [21].

The flexural tensile strengths of the concrete studied are given in table III. It can be seen that $50 \%$ replacement of coarse aggregates by limestone developed higher flexural tensile strength than $100 \%$ replacement of coarse aggregates by limestone did at 28 days of age and beyond.

In general, both concretes developed satisfactory flexural tensile strengths of 6.76 and $5.96 \mathrm{MPa}$ at 28 days of age, respectively. Generally, for structural lightweight concrete the compressive strength is over $15 \mathrm{MPa}$ and the flexural tensile strength is over $3 \mathrm{MPa}$. These results indicate that the lightweight aggregate using $50 \%$ limestone could be applied to structural lightweight concrete products [22]. The increase in the flexural tensile strength has the advantage that the corrosion resistance of such concrete will be improved. The 
flexural tensile strength of concrete is one of the parameters that control the rate of reinforcement corrosion. Therefore, increased flexural tensile strength of concrete indicates the potential for an increase in the useful service life of the concrete structures [23]. There is positive effect of the lower elastic modulus on the reduction of tensile thermal stress of surface layer of fine aggregate concrete, which reduces the possibility of concrete cracking. However, it should be noted that the reduction of splitting tensile strength will decrease the ability of surface layer of fine aggregate concrete to resist cracking [24]. The flexural strength is more sensitive to inner structure characteristic (such as porosity and microcracks) than to compressive strength [25].

There is only limited reliable information available on the Poisson's ratio of lightweight concrete in tension and in compression. The major difficulty in Poisson's ratio tests is to measure accurately the lateral strain which is rather small compared with the axial strain.

The 28-day Poisson's ratio of the concrete samples was varied between 0.16 and 0.11 which is similar to that reported by others [19].

\section{CONCLUSIONS}

It is confirmed that limestone can be used as a resource in concrete production and can be used in low cost construction especially in seismic zones. Concrete with 50\% replacement level of limestone which attained $23.10 \mathrm{MPa}$ compressive and $6.76 \mathrm{MPa}$ flexural tensile strength values, satisfies the requirements for a building material to be used in the structural applications. Contrary Concrete with 100\% replacement level of limestone which attained $12.10 \mathrm{MPa}$ compressive and 5.96 MPa flexural tensile strength values satisfies the requirements for lightweight concrete block. Further tests should be performed in order to analyze other mechanical properties. This experimental work showed that limestone can be used for the production of concrete with acceptable mechanical properties. However the complete investigation of limestone concrete, should include further tests concerning mainly with their durability. To investigate the utilization of limestone dust for the production of high strength building products, like concrete paving blocks, new specimens with higher cement content must be prepared and tested. Also the use of other types of cements, like cements with high Blaine value, may be investigated.

\section{REFERENCES}

[1] V. Ducman, B. Mirtic, "The applicability of different waste materials for the production of lightweight aggregate", Waste Manage. 29 (2009) 2361-2368.

[2] H. Tanyildizi, "Statistical analysis for mechanical properties of polypropylene fiberreinforced lightweight concrete containing silica fume exposed to high temperature", Mater. Design 30 (2009) 3252-3258.

[3] E. Yasar, C.D. Atis, A. Kilic, H. Gulsen, "Strength properties of lightweight concrete made with basaltic pumice and fly ash", Mater. Lett. 57 (2003) 2267- 2270.

[4] S. Kitouni, H. Houari, "Lightweight concrete with Algerian limestone dust. Part I: Study on 30\% replacement to normal aggregate at early age", Cerâmica 59 (2013) 600608.

[5] F. Altun, T. Haktanir, "Flexural behaviour of composite reinforced concrete elements", J. Mater. Civil. Eng. ASCE. 13 (2001) 255-259.

[6] R. Demirboga, R. . Orung, R. Gul, "Effects of expanded perlite aggregate and mineral admixtures on the compressive strength of low-density concretes", Cement Concrete Res. 31 (2001) 1627-1632.

[7] S. Rana, N. Norizal, T. D. Eethar,Z. S. Mohd, "Comparison between ribbed slab structure using lightweight foam concrete and solid slab structure using normal concrete", Concr. Res. Lett. 1 (2010) 19-34.

[8] R. Werasak, J. Meng, "Analysis modelling of seismic behaviour of lightweight concrete shear walls", International Multi Conference of Engineers and Computer Scientists, Hong Kong (2009) 1-6.

[9] T. Chao-Wei, F. Kuo-haung, T. Wen-Po, C. How-Ji, "Properties of lightweight concrete masonry units made from lightweight aggregates", Adv. Mater. Res. 150-151 (2011) 1588-1594.

[10] L.M. Silva, R.A. Ribeiro, J.A. Labrincha, V.M. Ferreira, "Role of lightweight fillers on the properties of a mixedbinder mortar", Cement Concrete Comp. 32 (2010) 19-24.

[11] Y. Jiakuan, L. Wanchao, Z. Lili, X. Bo, "Preparation of load-bearing building materials from autoclaved phosphogypsum", Constr. Build. Mater. 23 (2009)687-693. [12] P.J. Ramadhansyah, H.A.B. Badorul, A. Megat, J. Megat, H. Mohd, I. Wan,"Strength and permeability properties of concrete containing rice husk ash with different grinding time", Cent.Eur. J. Eng.1(2011) 103-112.

[13] C.L. Hwang, M.F. Hung, "Durability design and performance of self consolidating lightweight concrete", Const. Build. Mater. 19 (2005) 619-626.

[14] B. González-Corrochano, J. Alonso-Azcárate, M. Rodas, "Characterization of lightweight aggregates manufactured from washing aggregate sludge and fly ash", Resour.Conserv.Recy. 53 (2009) 571-581.

[15] A. K. Padmini, K. Ramamurthy, M.S. Mathews, "Influence of parent concrete on the properties of recycled aggregate concrete", Const. Build. Mater. 23 (2009) 829836.

[16] M. Khandaker, A. Hossain, "Properties of volcanic pumice based cement and lightweight concrete", CementConcrete Res. 34 (2004) 283-291.

[17] R. V. Balendran, "Estimating the elastic modulus of concrete made with artificially manufactured lightweight aggregates", Struct.Surv. 13 (1995) 16-20.

[18] Y. Keun-Hyeok, S. Jin-Kyu, L. Jae-Sam, Properties of alkali-activated mortar and concrete using lightweight aggregates", Mater.Struct. 43 (2010) 403-416.

[19] S.C. Kou, G.C. Lee, S.W. Poon, L. Lai, "Properties of lightweight aggregate concrete prepared with PVC granules derived from scraped PVC pipes", Waste Manage. 29 (2009) 
621-628.

[20] P. Turgut, H.M. Algin, "Limestone dust and wood sawdust as brick material", Build. Environ. 42 (2007) 33993403.

[21] A. Bengi, W. Hwai-Chung, "Material characteristics of high performance lightweight concrete reinforced with PVA, Constr. Build. Mater. 22 (2008) 635-645.

[22] K.J. Mun, "Development and tests of lightweight aggregate using sewage sludge for nonstructural concrete", Constr. Build. Mater. 21 (2007) 1583-1588.
[23] M. Mouli, H. Khelafi, "Performance characteristics of lightweight aggregate concrete containing natural pozzolan", Build. Environ. 43 (2008) 31-36.

[24] Z. Shunbo, L. Na, L. Lixin, S. Li, Y. Su, "Experimental study on mechanical properties of fine aggregate concrete made after wet-sieving coarse aggregate", Adv. Mater. Res. 168-170 (2011) 2200-2203.

[25] P. Turgut, "Masonry composite material made of limestone powder and fly ash", Powder Technol. 204 (2010) 42-47.

(Rec. 27/07/2015, Rev. 20/08/2015, Ac. 21/08/2015) 